\title{
Nocardioides koreensis sp. nov., Nocardioides bigeumensis sp. nov. and Nocardioides agariphilus sp. nov., isolated from soil from Bigeum Island, Korea
}

\author{
Correspondence \\ Chang-Jin Kim \\ changjin@kribb.re.kr
}

\author{
Syed G. Dastager, Jae-Chan Lee, Yoon-Jung Ju, Dong-Jin Park \\ and Chang-Jin Kim
}

\author{
Functional Metabolomics Research Center, KRIBB, Daejeon 305-806, Republic of Korea
}

\begin{abstract}
Three Gram-positive, coccoid to rod-shaped actinobacteria, designated strains MSL-09 ${ }^{\top}$, MSL$19^{\top}$ and MSL-28 $8^{\top}$, were isolated from a soil sample collected from Bigeum Island in Korea, and were subjected to a polyphasic taxonomic analysis. All three isolates grew optimally at $\mathrm{pH}$ 7.5-9.0 and $28-30{ }^{\circ} \mathrm{C}$. $16 \mathrm{~S}$ rRNA gene analysis revealed that all three strains belonged to the genus Nocardioides, with strains MSL-09 ${ }^{\top}, \mathrm{MSL}-19^{\top}$ and $\mathrm{MSL}-28^{\top}$ respectively showing the highest sequence similarity to Nocardioides aquaticus DSM $11439^{\top}(96.25 \%)$, Nocardioides aquiterrae GW-9 ${ }^{\top}(95.75 \%)$ and Nocardioides terrigena DS-17 $7^{\top}$ (95.61 \%).

Chemotaxonomically, they contain LL-2,6-diaminopimelic acid in the cell-wall peptidoglycan, MK$8\left(\mathrm{H}_{4}\right)$ as the predominant menaquinone and diphosphatidylglycerol, phosphatidylglycerol and some unknown lipids as the polar lipids found in the cell wall. iso- $\mathrm{C}_{16: 0}$ is a major fatty acid. The $\mathrm{G}+\mathrm{C}$ content of the DNA was respectively $69.9,69.3$ and $69.4 \mathrm{~mol} \%$ for strains MSL-09 ${ }^{\top}, \mathrm{MSL}-$ $19^{\top}$ and MSL-28 ${ }^{\top}$. Based on morphological, physiological, biochemical and chemotaxonomic characters presented in this study, the three strains represent novel species of the genus Nocardioides. The names Nocardioides koreensis sp. nov. (type strain MSL-09 ${ }^{\top}=$ KCTC $19272^{\top}$ $=$ DSM 19266 ${ }^{\top}$ ), Nocardioides bigeumensis sp. nov. (type strain MSL-19 ${ }^{\top}=$ KCTC $19290^{\top}$ $=$ DSM 19320 $0^{\top}$ and Nocardioides agariphilus sp. nov. (type strain MSL-28 ${ }^{\top}=K^{2}$ KCTC $19276^{\top}$ $=$ DSM $19323^{\top}$ ) are proposed.
\end{abstract}

The genus Nocardioides was proposed by Prauser (1976) for Gram-positive, non-acid-fast, aerobic and mesophilic nocardioform actinomycetes that develop a mycelium that fragments into irregular rod- to coccus-like elements. Originally, the genus contained two species, Nocardioides albus and Nocardioides luteus (Prauser, 1984), and, at the time of writing, the genus harbours 23 recognized species. In this study, isolates MSL- $09^{\mathrm{T}}, \mathrm{MSL}-19^{\mathrm{T}}$ and MSL- $28^{\mathrm{T}}$ were the subject of a taxonomic investigation.

Strain MSL-09 ${ }^{\mathrm{T}}$, MSL- $19^{\mathrm{T}}$ and MSL- $28^{\mathrm{T}}$ were isolated from a soil sample collected from Bigeum Island in Korea using R2A (1:10-diluted) medium (Difco). The isolates were routinely maintained on $\mathrm{R} 2 \mathrm{~A}$ (1:2-diluted) medium at $28{ }^{\circ} \mathrm{C}$ and maintained as glycerol suspensions $(20 \%$, w/v) at $-70{ }^{\circ} \mathrm{C}$. Morphological, physiological, cultural and biochemical properties were examined as described by

Abbreviation: DAP, 2,6-diaminopimelic acid.

The GenBank/EMBL/DDBJ accession numbers for the 16S rRNA gene sequences of strains MSL-09 ${ }^{\top}, \mathrm{MSL}-19^{\top}$ and MSL-28 ${ }^{\top}$ are respectively EF466115, EF466114 and EF466113.

Scanning electron micrographs of cells of the novel strains are available as supplementary material with the online version of this paper.
Yoon \& Park (2006). Morphological properties were examined by light microscopy (model Nikon HFX-DX) and electron microscopy (JEOL apparatus Philips SEM $515)$. Growth in the presence of $\mathrm{NaCl}$ was investigated in 2fold-diluted R2A at various $\mathrm{NaCl}$ concentrations (0.5$7.0 \%, \mathrm{w} / \mathrm{v}$, at intervals of $0.5 \%)$. The $\mathrm{pH}$ range for growth was determined by adjusting the $\mathrm{pH}$ at intervals of $0.5 \mathrm{pH}$ units from $\mathrm{pH} 4.5$ to 12.0 . The $\mathrm{pH}$ was adjusted prior to sterilization by the addition of $\mathrm{HCl}$ or $\mathrm{Na}_{2} \mathrm{CO}_{3}$. Metabolic properties were determined using API ZYM test kits (bioMérieux) according to the manufacturer's instructions. Physiological and biochemical characteristics were examined at $28{ }^{\circ} \mathrm{C}$ and properties were recorded after 7-10 days except for the nitrate reduction test, which was recorded after 2-3 days. Other tests, including cell morphology, motility, acid production and assimilation of carbon sources, were performed as described by Kämpfer (1991). Cell biomass for DNA extraction and for analyses of cellwall and isoprenoid quinones was obtained by cultivation at $28{ }^{\circ} \mathrm{C}$ in 2-fold-diluted R2A broth (pH 7.5). Chemotaxonomic and molecular systematic studies were performed as described by Yoon et al. (2005a, b, c). The isomer type of the diamino acid in the cell-wall 
peptidoglycan was analysed using TLC according to the method described by Komagata \& Suzuki (1987). For fatty acid methyl ester analysis, cell mass of the strains was harvested from 2-fold-diluted R2A broth ( $\mathrm{pH} 7.5$ ) after incubation for 10 days at $28{ }^{\circ} \mathrm{C}$.

Morphological, cultural, physiological and biochemical characteristics of strains MSL- $09^{\mathrm{T}}, \mathrm{MSL}-19^{\mathrm{T}}$ and MSL- $28^{\mathrm{T}}$ are given in the species descriptions and presented in Table 1. Cells are coccoid to short rods, arranged singly or in groups (Supplementary Fig. S1, available in IJSEM Online). Extraction of chromosomal DNA, amplification and purification of the $16 \mathrm{~S}$ rRNA gene by PCR and direct sequencing of the purified PCR product were performed as described previously (Lee et al., 2000; Lee, 2006). Almostcomplete sequences of the 16S rRNA genes of strains MSL$09^{\mathrm{T}}(1398 \mathrm{nt}), \mathrm{MSL}-19^{\mathrm{T}}(1398 \mathrm{nt})$ and MSL-28 ${ }^{\mathrm{T}}$ (1426 nt) were compared with those of representatives of the family Nocardioidaceae using the CLUSTAL_X program (Thompson et al., 1997). Comparative 16S rRNA gene sequence analysis showed that strains MSL-09 ${ }^{\mathrm{T}}, \mathrm{MSL}-19^{\mathrm{T}}$ and MSL-28 ${ }^{\mathrm{T}}$ were affiliated phylogenetically to the genus Nocardioides (Fig. 1). In phylogenetic trees based on the neighbour-joining, maximum-parsimony (Kluge \& Farris, 1969) and maximum-likelihood (Felsenstein, 1981) algorithms, strain $\mathrm{MSL}-09^{\mathrm{T}}$ clustered with Nocardioides

Table 1. Differential phenotypic properties of strains $M S L-09^{\top}, M S L-19^{\top}$ and $M S L-28^{\top}$ and related Nocardioides species

Taxa: 1, MSL-09 ${ }^{\mathrm{T}} ; 2$, MSL-19 ${ }^{\mathrm{T}} ; 3$, MSL-28 ${ }^{\mathrm{T}} ; 4$, N. lentus; 5, N. aquaticus; 6, N. terrigena. Data for reference species were taken from Collins et al. (1994) and Yoon et al. $(1997,2004)$. +, Positive; -, negative; w, weakly positive; v, variable (reactions in parentheses are for the type strain); ND, no data available. All organisms are positive for Gram staining and esterase lipase (C8) activity, and all are negative for ribose utilization, aesculin hydrolysis and activities of $\beta$-glucuronidase, $N$-acetyl- $\beta$-glucosaminidase and $\alpha$-fucosidase.

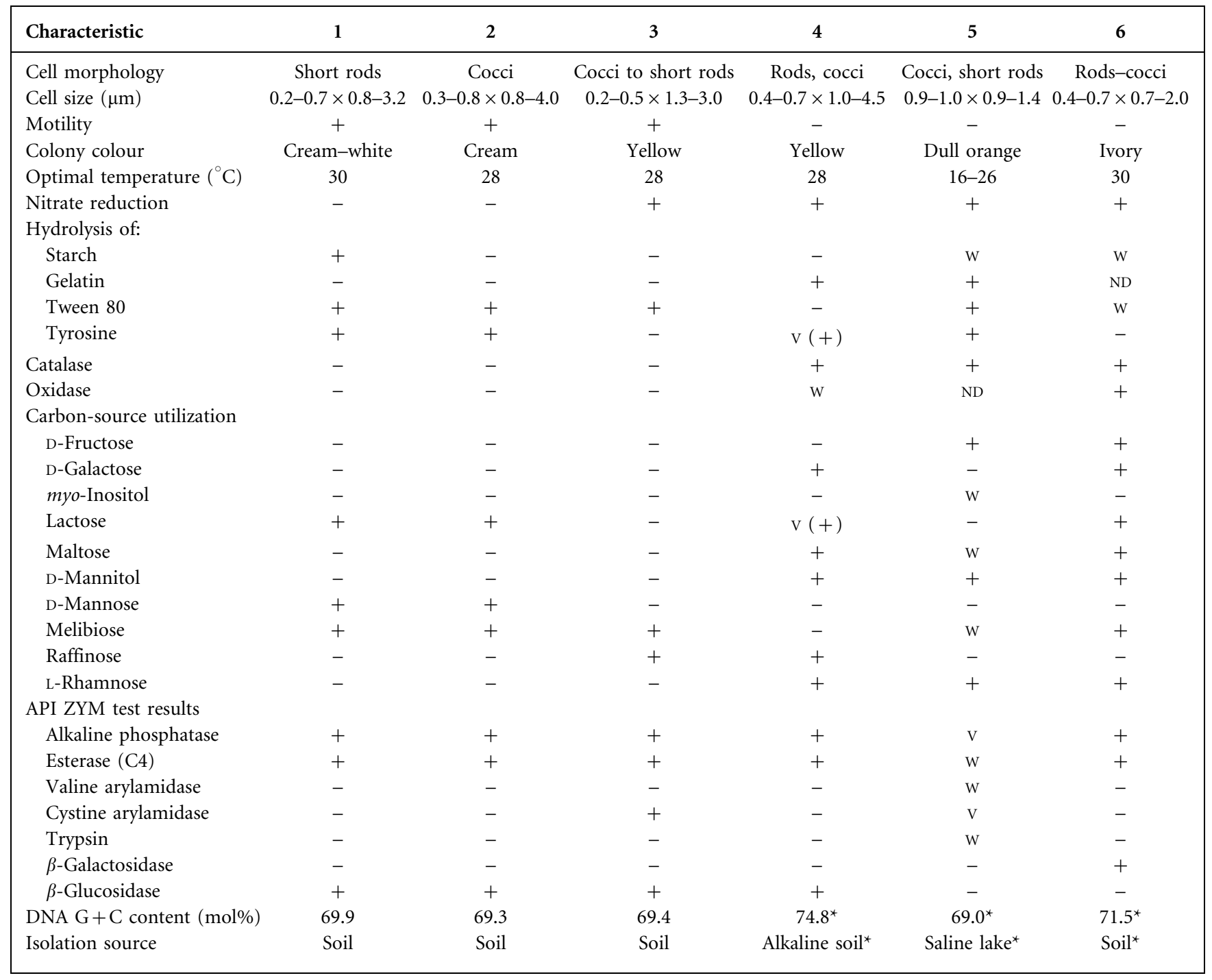

${ }^{\star}$ Data for the type strain. 


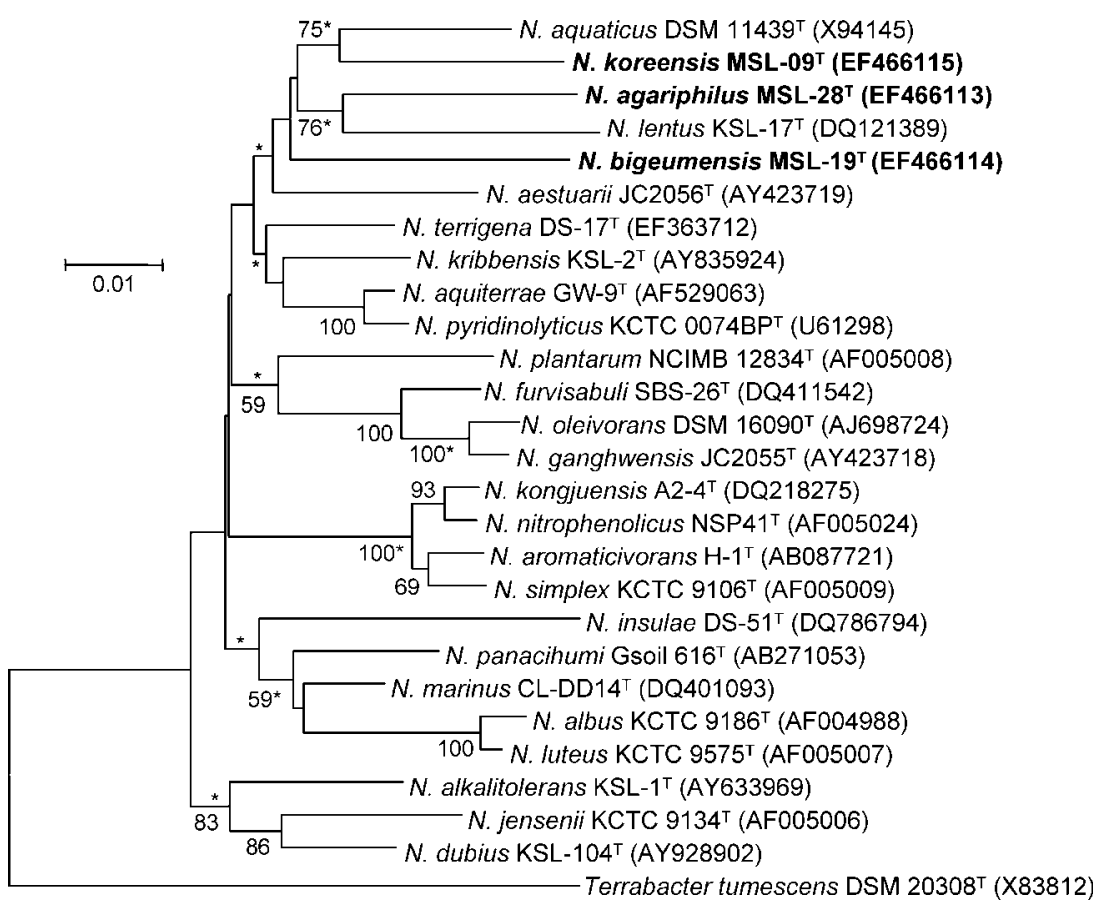

Fig. 1. Phylogenetic dendrogram obtained by neighbour-joining analysis based on $16 \mathrm{~S}$ rRNA gene sequences, showing the position of strains MSL- $9^{\top}, M S L-19^{\top}$ and MSL- $28^{\top}$ in the genus Nocardioides. Asterisks indicate branches that were also recovered using maximum-likelihood and maximum-parsimony. Terrabacter tumescens DSM $20308^{\top}$ served as the outgroup. Numbers on branch nodes are bootstrap values expressed as percentages (1000 resamplings). Bar, 0.01 substitutions per nucleotide position. aquaticus DSM $11439^{\mathrm{T}}$, MSL- $19^{\mathrm{T}}$ formed a separate lineage with Nocardioides aestuarii JC2056 ${ }^{\mathrm{T}}$ and MSL- $28^{\mathrm{T}}$ formed a cluster with Nocardioides lentus KSL-17 ${ }^{\mathrm{T}}$ (Fig. 1). The highest similarity values of the 16S rRNA gene sequences of strains MSL-09 ${ }^{\mathrm{T}}, \mathrm{MSL}-19^{\mathrm{T}}$ and MSL-28 ${ }^{\mathrm{T}}$ with those of recognized Nocardioides species were $96.25 \%\left(\mathrm{MSL}-09^{\mathrm{T}}\right.$, with Nocardioides aquaticus DSM $11439^{\mathrm{T}}$ ), $95.75 \%$ (MSL$19^{\mathrm{T}}$, with Nocardioides aquiterrae GW- $9^{\mathrm{T}}$ ) and $95.61 \%$ (MSL- $28^{\mathrm{T}}$, with Nocardioides terrigena DS- $17^{\mathrm{T}}$ ).

Strains MSL-0 $9^{\mathrm{T}}$, MSL- $19^{\mathrm{T}}$ and MSL- $28^{\mathrm{T}}$ contained LL-2,6diaminopimelic acid (LL-DAP) in the cell-wall peptidoglycan, the predominant menaquinone was $\mathrm{MK}-8\left(\mathrm{H}_{4}\right)$ and the polar lipids diphosphatidylglycerol, phosphatidylglycerol and some unidentified glycolipids were detected. The fatty acid profiles comprised large amounts of branched, unsaturated, straight-chain and 10-methyl fatty acids, as detailed in the species descriptions. The chemotaxonomic characteristics were consistent with the affiliation of the strains to the genus Nocardioides (Yoon et al., 1997, 2004, 2005a, b, c; Yoon \& Park, 2006). The DNA G + C content of strains MSL- $09^{\mathrm{T}}$, MSL- $19^{\mathrm{T}}$ and MSL- $28^{\mathrm{T}}$ was determined by reversed-phase HPLC of nucleosides according to Mesbah et al. (1989) and was 69.9, 69.3 and $69.4 \mathrm{~mol} \%$, respectively.

Phylogenetic analyses based on 16S rRNA gene sequences and chemotaxonomic data revealed that strains MSL- $09^{\mathrm{T}}$, MSL- $19^{\mathrm{T}}$ and MSL- $28^{\mathrm{T}}$ can be assigned to the genus Nocardioides (Urzì et al., 2000; Wang et al., 2001) as representatives of three novel species. This conclusion is supported by a number of phenotypic differences between the isolates and their phylogenetic neighbours (Table 1), as well as chemotaxonomic differences and fatty acid compositions. On the basis of the combination of physiological and chemotaxonomic properties and their phylogenetic distinctness, strains MSL-0 $09^{\mathrm{T}}, \mathrm{MSL}-19^{\mathrm{T}}$ and MSL- $28^{\mathrm{T}}$ represents novel members of the genus Nocardioides, for which the names Nocardioides koreensis sp. nov., Nocardioides bigeumensis sp. nov. and Nocardioides agariphilus sp. nov. are proposed.

\section{Description of Nocardioides koreensis sp. nov.}

Nocardioides koreensis (ko.re.en'sis. N.L. masc. adj. koreensis pertaining to Korea).

Cells are aerobic, non-spore-forming, Gram-positive, irregular short rods $(0.2-0.7 \times 0.8-3.2 \mu \mathrm{m})$. Colonies are circular, smooth, flat, cream to whitish in colour and 0.9$1.4 \mathrm{~mm}$ in diameter after 4-5 days incubation on R2A medium at $30{ }^{\circ} \mathrm{C}$. No formation of aerial or substrate mycelium. Growth occurs at $27-37{ }^{\circ} \mathrm{C}$ but not at or below $25^{\circ} \mathrm{C}$ or above $37{ }^{\circ} \mathrm{C}$. Optimum growth at $\mathrm{pH} 7.0-8.0$ and $30{ }^{\circ} \mathrm{C}$. Growth is observed in the presence $0-5 \% \mathrm{NaCl}$ (w/ v). Cellulose is not hydrolysed and tests for $\mathrm{H}_{2} \mathrm{~S}$ production, nitrate reduction, DNase and citrate hydrolysis are negative. Positive for starch hydrolysis. Cell-wall peptidoglycan contains LL-DAP as the diagnostic amino acid. The predominant menaquinone is $\mathrm{MK}-8\left(\mathrm{H}_{4}\right)$ and phospholipids are diphosphatidylglycerol, phosphatidylglycerol and some unknown phospholipids. Major fatty acids are $\mathrm{i}-\mathrm{C}_{16: 0}(62.87 \%), \mathrm{C}_{18: 1} \omega 9 \mathrm{c}(5.88 \%), \mathrm{i}-\mathrm{C}_{14: 0}$ (3.96\%), 10-methyl $\mathrm{C}_{17: 0}(3.42 \%), \mathrm{C}_{16: 0}(3.30 \%), \mathrm{i}-\mathrm{C}_{16: 1}$ $(3.13 \%)$, ai- $\mathrm{C}_{17: 0}(1.73 \%), \mathrm{C}_{18: 0}(1.57 \%), \mathrm{C}_{17: 1} \omega 8 \mathrm{c}$ $(1.33 \%), \mathrm{C}_{17: 0}(1.20 \%)$ and $\mathrm{i}-\mathrm{C}_{15: 0}(1.12 \%)$. The DNA $\mathrm{G}+\mathrm{C}$ content of the type strain is $69.9 \mathrm{~mol} \%$. Other phenotypic properties are given in Table 1 . 
The type strain, MSL- $09^{\mathrm{T}} \quad\left(=\mathrm{KCTC} 19272^{\mathrm{T}}=\mathrm{DSM}\right.$ $\left.19266^{\mathrm{T}}\right)$, was isolated from a soil sample collected from Bigeum Island, Republic of Korea.

\section{Description of Nocardioides bigeumensis sp. nov.}

Nocardioides bigeumensis (bi.ge.um.en'sis. N.L. masc. adj. bigeumensis pertaining to Bigeum Island, Korea, the source of the soil sample from which the type strain was isolated).

Cells are aerobic, non-spore-forming, Gram-positive, cocci to short rods $(0.3-0.8 \times 0.8-4.0 \mu \mathrm{m})$. Cells show coccus- to rod-like appearance from early exponential phase to stationary phase. Colonies are irregular, smooth, flat, cream in colour and $1.0-2.5 \mathrm{~mm}$ in diameter after 4 5 days incubation on $\mathrm{R} 2 \mathrm{~A}$ medium at $28{ }^{\circ} \mathrm{C}$. No aerial or substrate mycelium is observed. Growth occurs at 20 $35{ }^{\circ} \mathrm{C}$, with optimum growth at $28{ }^{\circ} \mathrm{C}$. Optimum $\mathrm{pH}$ for growth is $\mathrm{pH}$ 7.5-9.0. No growth is observed in the presence of $1 \% \mathrm{NaCl}$ or more. Cellulose, casein, starch and urea are not hydrolysed and tests for $\mathrm{H}_{2} \mathrm{~S}$ production, nitrate reduction, DNase and citrate hydrolysis are negative. Cell-wall peptidoglycan contains LL-DAP as the diagnostic diamino acid. MK- $8\left(\mathrm{H}_{4}\right)$ is the predominant menaquinone detected and diphosphatidylglycerol and phosphatidylglycerol are the phospholipids found in the cell wall. Major fatty acids are $\mathrm{i}-\mathrm{C}_{16: 0}(38.3 \%), \mathrm{i}-\mathrm{C}_{15: 0}$ (13.1\%), i-C $14: 0 \quad(9.0 \%), \mathrm{C}_{18: 1} \omega 9 c(6.25 \%)$, 10-methyl $\mathrm{C}_{16: 0}(4.8 \%), \mathrm{C}_{16: 0}(4.40 \%), \mathrm{C}_{17: 1} \omega 8 c(3.9 \%), \mathrm{C}_{17: 0}$ (3.0\%), 10-methyl $\mathrm{C}_{17: 0}(1.9 \%)$, ai- $\mathrm{C}_{15: 0}(1.6 \%)$, ai- $\mathrm{C}_{17: 0}$ $(1.2 \%), \mathrm{C}_{15: 0}(1.1 \%)$ and $\mathrm{i}-\mathrm{C}_{16: 1}(1.1 \%)$. The DNA G +C content of the type strain is $69.3 \mathrm{~mol} \%$. Other phenotypic properties are given in Table 1.

The type strain, MSL- $19^{\mathrm{T}}\left(=\mathrm{KCTC} 19290^{\mathrm{T}}=\mathrm{DSM} 19320^{\mathrm{T}}\right)$, was isolated from soil from Bigeum Island, Republic of Korea.

\section{Description of Nocardioides agariphilus sp. nov.}

Nocardioides agariphilus (a.ga.ri.phi'lus. N.L. n. agarum agar; Gr. adj. philos loving; N.L. masc. adj. agariphilus agar-loving).

Cells are aerobic, non-spore-forming, Gram-positive cocci to short rods $(0.2-0.5 \times 1.3-3.0 \mu \mathrm{m})$. Cells show rod-to-coccuslike appearance (Fig. 1). Colonies are irregular, smooth, flat, white to cream in colour and $1.5-2.7 \mathrm{~mm}$ in diameter after 7 days incubation on $\mathrm{R} 2 \mathrm{~A}$ medium at $28{ }^{\circ} \mathrm{C}$. Good growth is observed on agar without any addition of carbon and nitrogen sources. No aerial or substrate mycelium is formed, even after long incubation (40 days). Growth occurs at 25$37{ }^{\circ} \mathrm{C}$ but not at or below $20{ }^{\circ} \mathrm{C}$ or above $37{ }^{\circ} \mathrm{C}$. Optimum $\mathrm{pH}$ for growth is 7.5 . No growth in $2 \% \mathrm{NaCl}$ or more. Cellulose is not hydrolysed and tests for $\mathrm{H}_{2} \mathrm{~S}$ production, DNase and citrate hydrolysis are negative. Nitrate is reduced to nitrite. Cell-wall peptidoglycan contains LL-DAP as the diagnostic diamino acids. Predominant menaquinone is MK$8\left(\mathrm{H}_{4}\right)$ and diphosphatidylglycerol and phosphatidylglycerol are the phospholipids found in the cell wall. Major fatty acids are $\mathrm{i}-\mathrm{C}_{16: 0}(37.63 \%), \mathrm{C}_{17: 1} \omega 8 c(9.75 \%), \mathrm{C}_{17: 0}(7.06 \%)$, i$\mathrm{C}_{17: 0} \quad(5.81 \%), \quad \mathrm{i}-\mathrm{C}_{17: 1} \omega 9 \mathrm{c} \quad(5.06 \%), \quad \mathrm{i}-\mathrm{C}_{15: 0} \quad(4.90 \%)$, $\mathrm{C}_{18: 1} \omega 9 c \quad(4.33 \%), \quad$ ai- $\mathrm{C}_{17: 0} \quad(3.90 \%), \quad 10$-methyl $\mathrm{C}_{17: 0}$ $(2.99 \%), \mathrm{C}_{16: 0}(2.55 \%)$ and $\mathrm{C}_{18: 0}(2.39 \%)$. The DNA $\mathrm{G}+\mathrm{C}$ content of the type strain is $69.4 \mathrm{~mol} \%$. Other phenotypic properties are given in Table 1.

The type strain, MSL-28 ${ }^{\mathrm{T}}\left(=\right.$ KCTC $\left.19276^{\mathrm{T}}=\mathrm{DSM} 19323^{\mathrm{T}}\right)$, was isolated from a soil sample collected from Bigeum Island, Republic of Korea.

\section{Acknowledgements}

This work was supported by the 21C Frontier Microbial Genomics and Application Centre program of the Korean Ministry of Science \& Technology (MOST) and the Korea Foundation for International Cooperation of Science \& Technology (KICOS) through a grant provided by MOST in the Global Partnership Program (no. M60602000001-06E0200-00100), Republic of Korea.

\section{References}

Collins, M. D., Cockcroft, S. \& Wallbanks, S. (1994). Phylogenetic analysis of a new LL-diaminopimelic acid-containing coryneform bacterium from herbage, Nocardioides plantarum sp. nov. Int J Syst Bacteriol 44, 523-526.

Felsenstein, J. (1981). Evolutionary tree from DNA sequences: a maximum likelihood approach. J Mol Evol 17, 368-376.

Kämpfer, P. (1991). Application of miniaturized physiological tests in numerical classification and identification of some bacilli. J Gen Appl Microbiol 37, 225-247.

Kluge, A. G. \& Farris, F. S. (1969). Quantitative phyletics and the evolution of anurans. Syst Zool 18, 1-32.

Komagata, K. \& Suzuki, K. (1987). Lipid and cell-wall analysis in bacterial systematics. Methods Microbiol 19, 161-203.

Lee, S. D. (2006). Kineococcus marinus sp. nov., isolated from marine sediment of the coast of Jeju, Korea. Int J Syst Evol Microbiol 56, 1279-1283.

Lee, S. D., Kang, S.-O. \& Hah, Y. C. (2000). Hongia gen. nov., a new genus of the order Actinomycetales. Int J Syst Evol Microbiol 50, 191-199.

Mesbah, M., Premachandran, U. \& Whitman, W. B. (1989). Precise measurement of the $\mathrm{G}+\mathrm{C}$ content of deoxyribonucleic acid by high performance liquid chromatography. Int J Syst Bacteriol 39, 159-167.

Prauser, H. (1976). Nocardioides, a new genus of the order Actinomycetales. Int J Syst Bacteriol 26, 58-65.

Prauser, H. (1984). Nocardioides luteus spec. nov. Z Allg Mikrobiol 24, 647-648.

Thompson, J. D., Gibson, T. J., Plewniak, F., Jeanmougin, F. \& Higgins, D. G. (1997). The CLUSTAL_X windows interface: flexible strategies for multiple sequence alignment aided by quality analysis tools. Nucleic Acids Res 25, 4876-4882.

Urzì, C., Salamone, P., Schumann, P. \& Stackebrandt, E. (2000). Marmoricola aurantiacus gen. nov., sp. nov., a coccoid member of the family Nocardioidaceae isolated from a marble statue. Int J Syst Evol Microbiol 50, 529-536.

Wang, Y. M., Zhang, Z. S., Xu, X. L., Ruan, J. S. \& Wang, Y. (2001). Actinopolymorpha singaporensis gen. nov., sp. nov., a novel actinomycete from the tropical rainforest of Singapore. Int J Syst Evol Microbiol 51, 467-473.

Yoon, J.-H. \& Park, Y.-H. (2006). The genus Nocardioides. In The Prokaryotes. A Handbook on the Biology of Bacteria, 3rd edn, vol. 3, pp. 
1099-1113. Edited by M. Dworkin, S. Falkow, E. Rosenberg, K. H. Schleifer \& E. Stackebrandt. New York: Springer.

Yoon, J.-H., Rhee, S.-K., Lee, J.-S., Park, Y.-H. \& Lee, S. T. (1997). Nocardioides pyridinolyticus sp. nov., a pyridine degrading bacterium isolated from the oxic zone of an oil shale column. Int J Syst Bacteriol 47, 933-938.

Yoon, J.-H., Kim, I.-G., Kang, K. H., Oh, T.-K. \& Park, Y.-H. (2004). Nocardioides aquiterrae sp. nov., isolated from groundwater in Korea. Int J Syst Evol Microbiol 54, 71-75.
Yoon, J.-H., Kim, I.-G., Lee, M.-H., Lee, C.-H. \& Oh, T.-K. (2005a). Nocardioides alkalitolerans sp. nov., isolated from an alkaline serpentinite soil in Korea. Int J Syst Evol Microbiol 55, 809-814.

Yoon, J.-H., Kim, I.-G., Lee, M.-H. \& Oh, T.-K. (2005b). Nocardioides kribbensis sp. nov., isolated from an alkaline soil. Int J Syst Evol Microbiol 55, 1611-1614.

Yoon, J.-H., Lee, C.-H. \& Oh, T.-K. (2005c). Nocardioides dubius sp. nov., isolated from an alkaline soil. Int J Syst Evol Microbiol 55, 2209-2212. 